\title{
On Some Problems of Commercial Law in Ukraine ${ }^{1}$
}

\section{Oleksandr Romanovich Kovalyshyn}

Abstract: The paper is devoted to the disclosure of certain aspects of recodification in Ukraine, some existing problems of the Ukrainian commercial law as well as the conflict of norms between the Commercial Code of Ukraine and the Civil Code of Ukraine. In year 2020, the Concept of Civil Legislation Reform was adopted in Ukraine. The Concept of Civil Legislation Reform states that the systematic renewal of the Civil Code of Ukraine as a whole is possible only if the Commercial Code of Ukraine is repealed because the latter does not meet the parameters of the acts governing business relations which, by their nature, are primarily private. The presented study explains the current problems of the Ukrainian commercial law as well as civil law regulation of business relations for both: 1) the foreign scholars dealing with the civil law and commercial law; 2) the foreign investors (including investors from the European Union countries) who are already conducting economic activities in Ukraine or plan to invest in the Ukrainian economy. Special attention is given to such issues like the types of ownership, penalties for obligations, differences in legal capacity, difference of approaches to the system of legal entities, existence of some archaic legal forms of entrepreneurial activity, etc. The author emphasizes that undoubtedly the Commercial Code of Ukraine as well as the Civil Code of Ukraine need some updating. There is an urgent need to systematize the existing organizational and legal forms of legal entities and to renew the basics of civil law regulation in Ukraine. It is explained in the paper, while in most neighbouring jurisdictions steps are being taken to systematic update of the commercial codes (including expanding the scope of their legal regulations), in Ukraine steps are being taken to eliminate the commercial code. This seems completely unacceptable; it harms the legal regulation of business relations in Ukraine significantly and slows down the progressive development of the Ukraine's economy. The analysis of the commercial codes abroad shows that there is no single approach to the list of legal constructions that should form the basis of the relevant code. All, without ex-

\footnotetext{
1 This paper was written in the framework of the Jean Monnet Module "Commercial Law of the European Union", No. 600196-EPP-1-2018-1-UA-EPPJMO-MODULE and was financed with the support of the Erasmus+ Programme of the European Union.
} 
ception, codified acts of this type are characterized by the presence of special institutions that, from the point of foreign lawyer's view or current trends in private law, may seem do not meet certain standards.

Key Words: Civil Law; Commercial Law; Company Law; Civil Code of Ukraine; Commercial Code of Ukraine; Recodification; Comparison; Ukraine.

\section{Introduction}

On July 17, 2019, the Cabinet of Ministers of Ukraine adopted a resolution under No. 650 "On the Establishment of a Working Group on Recodification (Updating) of Civil Legislation of Ukraine", which formed a working group on recodification of the civil legislation. ${ }^{2}$

The main tasks of the above-mentioned working group were identified by the Ukrainian government as following: 1) conducting a comprehensive analysis of the existing civil legislation of Ukraine and identifying areas of the private and commercial law relations that need to be brought into line with global trends in private law; 2) studying the experience of the European countries on recodification (updating) their civil and commercial legislations; 3) elaborating of proposals for recodification (updating) of the civil legislation of Ukraine.

This study is devoted to the disclosure of certain aspects of recodification of the civil legislation of Ukraine, some existing problems of commercial law as well as the conflict of norms between the Commercial Code of Ukraine ${ }^{3}$ and the Civil Code of Ukraine. ${ }^{4}$

Ukraine has adopted a different way of solving the problem of dualism in the practice of regulating the commercial and corporate relations. In year 2004, two codified acts were adopted simultaneously: 1) the Civil Code of Ukraine, which included at the same time the norms of contractual, non-contractual and inheritance law; 2) the Commercial Code of Ukraine, which contained rules governing not only the legal relations

2 See Resolution of the Cabinet of Ministers of Ukraine on the Establishment of a Working Group on Recodification (Updating) of Civil Legislation of Ukraine No. 650 [2019-07-17] [online]. 2019 [cit. 2021-03-31]. Available at: https://www.kmu.gov.ua/npas/proutvorennya-robochoyi-grupi-shchodo-rekodifikaciyi-onovlennya-civilnogo-zakonodavstva-ukrayini-s-650-170719.

3 See Commercial Code of Ukraine [online]. 2021 [cit. 2021-03-31]. Available at: https:// zakon.rada.gov.ua/laws/show/436-15.

4 See Civil Code of Ukraine [online]. 2021 [cit. 2021-03-31]. Available at: https://zakon.rada.gov.ua/laws/show/435-15. 
within the commercial companies and business agreements, but also a significant array of rules relating to the property of economic entities, general provisions on economic obligations, liability for economic offences, special features of legal regulation in some sectors of economy, foreign economic activity, special regimes of carrying out economic activity, and so on.

The dualism of law is a legal solution that is typical in many European Union states as well as in some post-Soviet countries. Some examples of the coexistence of both the civil and the commercial (which is more than a codification of norms on companies and associations) codes will be given below.

The adoption of the two mentioned codes led to a number of problems in the legal regulation of commercial relations in Ukraine in practice. The presented paper concentrates on the disclosure and analysis of these inconsistencies. In our opinion, this study will be useful for: 1) the foreign scholars dealing with the civil law and commercial law; 2) the foreign investors (including investors from the European Union countries) who are already conducting economic activities in Ukraine or plan to invest in the Ukrainian economy.

\section{Some conflicts in commercial relations' regulation}

Problems of legal regulation are related to the inconsistencies in the law of the both Codes. It should be noted that the most important and acute problems arise in such fields like the property, legal entities and obligations regulated under the Civil Code of Ukraine and the Commercial Code of Ukraine.

Types of ownership. The Article 63 of the Commercial Code of Ukraine introduces the concept of a mixed form of ownership, namely, collective ownership.

At the same time, the Constitution of Ukraine and the Civil Code of Ukraine define only the private, state and communal property and do not distinguish the mixed (or collective) form of ownership. The collective form of ownership lost its significance as a remnant of the Soviet law, when the collective ownership was the dominant form of ownership.

Penalties for obligations. A different approach is used in determining the fines. In accordance with the Article 232 of the Commercial Code of Ukraine, if for non-performance or improper performance of obligations 
penalties were imposed, the damages are reimbursed in the part not covered by these sanctions.

On the other hand, the Article 624 of the Civil Code of Ukraine states: "If a penalty (fine) is imposed for a breach of obligation, it is subject to recovery in full, regardless of the damages." The contract may establish an obligation to reimburse damages only insofar as they are not covered by the penalty. The difference is that the Commercial Code of Ukraine applies an imperative approach to the application of fines in obligations, while the Civil Code of Ukraine proposes for the parties to determine the ratio of damages and penalties on the basis of the dispositive method.

Differences in legal capacity. According to the Civil Code of Ukraine, legal entities have a universal legal capacity, i.e. a legal entity is capable of having the same civil rights and obligations (civil legal capacity) as an individual. Thus, the Article 91 of the Civil Code of Ukraine stipulates that a legal entity is capable of having the same civil rights and obligations (civil legal capacity) as a natural person, except for those which by their nature can belong only to a person.

At the same time, the provisions of the Commercial Code of Ukraine provide for a special legal capacity, when a legal entity has just such rights and obligations that correspond to the purpose and objectives of its activities (Articles 57 and 207 of the Commercial Code of Ukraine).

Difference of approaches to the system of legal entities. In the terms of methodology, there are two different systems of legal persons in the Ukrainian law - system provided for by the Civil Code of Ukraine and system under the Commercial Code of Ukraine. Under the Civil Code of Ukraine, legal persons are divided into legal persons of public law and legal persons of private law (Article 81 of the Civil Code of Ukraine). Legal persons may be set up in the form of companies, institutions and in other forms established by the law (Article 63 of the Civil Code of Ukraine). Under the Commercial Code of Ukraine, depending on the way of their formation (foundation) and formation of the authorized capital, legal persons are divided into unitary enterprises and corporate enterprises. Unitary enterprises mean state or communal enterprises, enterprises based on the property of association of citizens, religious organization or on private property of the founder (Article 63 (III - V) of the Commercial Code of Ukraine). Other laws provide for other forms (types) of legal persons. 
As a result, there are more than 80 legal forms of entrepreneurs which impede legal definiteness and established development in the commercial area, because the Ukrainian law does not contain an exhaustive list of types (forms) of legal entities (persons).

Existence of some archaic legal forms of entrepreneurial activity. In the past, it was an obligatory condition for the limited liability companies, additional liability companies and joint-stock companies to have a minimum of three founders. Therefore, a private enterprise was popular as a type of company with one owner and without obligatory minimal capital. Nowadays, the limited liability companies, additional liability companies as well as joint-stock companies may be established by one person who becomes the sole shareholder (founder). Therefore, the question arises: is there a need to preserve such type of legal entity as a private enterprise which, according to the Article 113 of the Commercial Code of Ukraine, is an enterprise operating on the basis of private property of one or more citizens, foreigners, persons without citizenship? In fact, an enterprise operating on the basis of private property of a legal entity or a natural person is a limited liability company, but with some restrictions.

Different approaches to understanding the essence of the enterprise in the theory of law. In the Ukrainian law, there are different approaches to the definition of an enterprise. An enterprise is an object in the civil legal relations (according to the Civil Code of Ukraine); or an enterprise is a subject, an economic entity (according to the Commercial Code of Ukraine). The Commercial Code of Ukraine discloses the concept of enterprise as an independent business entity established by a competent public authority or a local government or by other entities to meet the public and personal needs through a systematic implementation of production, research, trade and other economic activities in the manner prescribed by the Commercial Code of Ukraine and other laws (Article 62). In contrast, the Civil Code of Ukraine stipulates that an enterprise is a joint property complex used for business activities (Article 191).

Ineffectiveness of partnerships in the Ukrainian company law. Statistics on numbers of registered partnerships in Ukraine clearly show that the full partnership and the limited partnership show a downward trend in absolute terms. The decline in numbers of registered businesses means, to some extent, a typical phenomenon in the economy of each country and is caused by various reasons: the financial crisis, changes in 
economic policy, fight against the "shadow business", changes in tax laws and others. For example, after the introduction of the mandatory single social contribution for individual entrepreneurs, the number of entrepreneurs in Ukraine fell sharply. This is due to a significant number of the so-called "sleeping individual entrepreneurs" who did not carry out systematic economic activity, but were active from time to time in order to optimize the taxation of other entities (usually legal entities). Unpopularity of partnerships is caused also by ineffective legal regulation of relations between partner and partnership, complicated founding of a limited partnership, and so on. In the absence of tax preferences, ${ }^{5}$ investors do not want to bear higher risks associated with the partnerships.

In Ukraine, there have been adopted two main approaches in the theory and court practice to the resolution of the above-mentioned legal conflicts: identifying the general norm and the special norm 1) in accordance with the scope of normative regulation; or 2) in accordance with the peculiarities of the mechanism of regulation. In the latter case, reference is made to the provision of the Part 2 of the Article 9 of the Civil Code of Ukraine, according to which the law may provide for peculiarities of regulation of property relations in the commercial area, and to the provision of the Part 2 of the Article 4 of the Commercial Code of Ukraine, according to which peculiarities of regulation of property relations of economic entities are established by the Commercial Code of Ukraine. Therefore, the main point of such approach is to identify the subjective composition of the participants. Supporters of this position consider that the general provisions of the Commercial Code of Ukraine are to be applied to the relations between entrepreneurial entities. If one of the subjects of some private relations is a natural person, then the provisions of the Civil Code of Ukraine are to be applied. ${ }^{6}$

\section{Dualism of private law: foreign experiences}

In most European countries, two codes coexist: the Civil Code as the basic codified act of private law and the Commercial Code (or the Companies

5 Limited partnerships and general partnerships are legal entities in the terms of tax law of Ukraine. They pay income taxes according to the Tax Code of Ukraine of 2 December 2010, No. 2755-VI, as amended.

6 See MAYDANYK, R. Contract and Corporate Law of Ukraine: Evolution and Trends. In: P. PINIOR, W. WYRZYKOWSKI and M. ŻABA, eds. Evolution of Private Law: New Perspectives. 1. wyd. Katowice: Oficyna Wydawnicza Wacław Walasek, 2018, pp. 54-65. ISBN 978-8365694-57-7. 
Act). In particular, codes of economic (trade) law were adopted and are functioning successfully in such European countries as France (Code de commerce), ${ }^{7}$ Germany (Handelsgesetzbuch), ${ }^{8}$ Austria (Unternehmensgesetzbuch), ${ }^{9}$ Poland (Kodeks spółek handlowych), ${ }^{10}$ the Czech Republic (Zákon o obchodních společnostech a družstvech (zákon o obchodních korporacích)), ${ }^{11}$ etc. The structure of these commercial codes differs.

The Commercial Code of France Code de commerce contains rules on the Commercial Act, on merchants, their status, responsibilities, cooperative retailers, mutual guarantee societies, brokers, commission agents, carriers as well as commercial agents. The Second Book of the Commercial Code of France entitled "On Business Companies and Associations of Economic Cooperation" is devoted not only to the national economic entities, but also to the European associations of economic cooperation. The Third Book "On Some Types of Sales" lays down rules on certain types of sales and conditions that apply to exclusive sales. A separate part is devoted to the procedures for pricing and competition (the Fourth Book "On Freedom of Price and Competition"). The Commercial Code of France also includes rules on the drafting and form of a bill of exchange, endorsement, acceptance, aval, payment and claims. There are also provisions on commercial collateral, rules for storage of goods in warehouses or accreditation of these warehouses (in the Fifth Book entitled "On Commercial Securities and Collateral").

The German law served as a model for the formation of not only business law, but also private law in a number of the Eastern European countries. In this case, the Commercial Code of Germany Handelsgesetzbuch contains rules for certain types of companies as well as rules for business contracts, register of legal entities, procedures for registration of business entities in the register, and so on. The Commercial Code of Germany defines the main economic entities - entrepreneur (Kaufmann),

7 See Code de commerce. 54e éd. Paris: Jurisprudence générale Dalloz, 1958. 963 p.

8 See Handelsgesetzbuch [online]. 2021 [cit. 2021-03-31]. Available at: https://www.gesetze-im-internet.de/hgb/.

9 See Unternehmensgesetzbuch [online]. 2021 [cit. 2021-03-31]. Available at: https://www. ris.bka.gv.at/GeltendeFassung.wxe?Abfrage=Bundesnormen $\&$ Gesetzesnummer $=1000170$ 2.

${ }^{10}$ See Kodeks spółek handlowych [online]. 2021 [cit. 2021-03-31]. Available at: http://isap. sejm.gov.pl/isap.nsf/download.xsp/WDU20000941037/U/D20001037Lj.pdf.

${ }^{11}$ See Zákon č. 90/2012 Sb. o obchodních společnostech a družstvech (zákon o obchodních korporacích) [online]. 2021 [cit. 2021-03-31]. Available at: https://www.zakonyprolidi. cz/cs/2012-90. 
their associations (Handelsgesellschaften), commercial representative (Handelsvertreter), broker (Handelsmakler); regulates the functioning of the Trade Register and the procedure for an entry in the Trade Register; defines trade agreements (Handelskäufe), commission transactions (Kommissionsgeschäfte), etc.; establishes rules for accounting, balance sheets, determination of financial results of the companies and many other aspects of economic activities.

The Austrian Commercial Code Unternehmensgesetzbuch contains legal norms on the basics of business (Book I entitled "General Provisions, Definition of Business Entity", § 1 "Entrepreneur and enterprise"), types of partnerships (Book II "General Partnership, Limited Partnership and Silent Partnership") as well as rules regulating business agreements (Book IV "Business Transactions"), accounting for business transactions (Book III "Accounting") or rules regulating certain areas of the economic turnover (Book V "Maritime Trade"). ${ }^{12}$

It is noteworthy that the Austrian Commercial Code contains rules governing the maritime transport, while Austria is landlocked and the maritime trade is not one of the leading sectors of the Austrian economy. The reason is that the Commercial Code was adopted at the time when Austria was a great empire with access to a number of the Mediterranean Sea countries. Despite the significant economic, political and territorial changes in the country, the Commercial Code continues to function with, to some extent, "archaic" provisions (Book V entitled "Maritime Trade"). The stability of its regulations is placed above the short-term situational changes. In addition, we would like to emphasize that the Austrian Commercial Code is not exclusively a "company code". Only Book II is devoted to the latter. Other provisions regulate various aspects of the economic turnover - from economic contracts (Book IV) to accounting (Book III).

Looking at the law of the neighbouring countries, it should be noted that the economic legislation of Poland has undergone significant reforms. For a considerable period of time, the country used its own Commercial Code (1934), which in many respects resembled the Commercial

${ }^{12}$ See VASYLIEVA, V. A. ed. Company Law of Austria and Ukraine: Monograph. IvanoFrankivsk: Vasyl Stefanyk Precarpathian National University, 2015. 250 p. ISBN 978-966640-411-7 [in the Ukrainian original ВАСИЛЬЄВА, В. А. ред. Корпоративне право Австрії та України: Монографія. Івано-Франківськ: Прикарпатський національний університет імені Василя Стефаника, 2015. 250 с. ISBN 978-966-640-411-7]. 
Code of Germany..$^{13}$ This can be seen in the borrowing of the structure of the German Commercial Code, the system of concepts (German - Händler, Polish - kupiec, etc.) as well as in the regulation of the system of obligations of economic entities and the presence of the so-called Introductory Law to the Commercial Code. According to Andrzej Szumański, the previous Polish Commercial Code was much more reminiscent of the Slavic interpretation of the German Handelsgesetzbuch than the current Code of Business Associations (2000). ${ }^{14}$

Despite the considerable discussions on the abolition of the Polish Commercial Code and proposals to unify economic legislation under the Polish Civil Code, such ideas have not been implemented. With the formation of the Commission on the Codification of Civil Law and the Subcommittee on the Reform of Corporate Law (composed of professors Stanisław Sołtysiński, Andrzej Szajkowski and Janusz Szwaja), ${ }^{15}$ the mentioned Code was reformed. As a result, the Code of Business Associations Kodeks spółek handlowych was adopted on the basis of discussions, while discussions on updating the Civil Code of Poland are ongoing. Despite the developers' desire to absorb economic norms under the civil law, this idea has not been realised. The Polish Code of Business Associations regulates the system as well as procedures of founding, reorganization and termination in relation to business associations.

In this context, it should be noted that there is also a single approach to the regulation of business relations in the United States of America. A model codified act of commercial law - the Uniform Commercial Code (Uniform Commercial Act) ${ }^{16}$ was taken as a basis by the most states. This

\footnotetext{
${ }^{13}$ See SOŁTYSIŃSKI, S. Reform of Polish Company Law. In: B. GROSSFELD, R. SACK, Th. M. J. MÖLLERS, J. DREXL and A. HEINEMANN, Hrsg. Festschrift für Wolfgang Fikentscher zum 70. Geburtstag. 1. Aufl. Tübingen: Mohr Siebeck, 1998, pp. 419-433. ISBN 3-16-146704-3.

${ }^{14}$ See SOŁTYSIŃSKI, S. and A. SZUMAŃSKI. Shareholder and Creditor Protection in Company Groups under Polish Law. In: K. J. HOPT, Ch. JESSEL-HOLST and K. PISTOR, Hrsg. Unternehmensgruppen in mittel- und osteuropäischen Ländern: Entstehung, Verhalten und Steuerung aus rechtlicher und ökonomischer Sicht. 1. Aufl. Tübingen: Mohr Siebeck, 2003, pp. 89-104. Beiträge zum ausländischen und internationalen Privatrecht, Nr. 76. ISBN 316-148089-9.

${ }^{15}$ See KOŁACZ, J. Polish Company Law: A Few Remarks on Legal History and Foreign Inspirations. Social Science Research Network Electronic Paper Collection [online]. 2009, no. 3, pp. 1-36 [cit. 2021-03-31]. Available at: https://doi.org/10.2139/ssrn.2020231.

${ }^{16}$ See MARTIN, J. S., C. P. MARKS and W. BARNES. The Uniform Commercial Code Survey: Introduction. The Business Lawyer. 2015, vol. 70, no. 4, pp. 1161-1164. ISSN 0007-6899; MENTSCHIKOFF, S. The Uniform Commercial Code. Rabels Zeitschrift für ausländisches und internationales Privatrecht [The Rabel Journal of Comparative and International Pri-
} 
document serves as a model for the legal regulation of commercial relations at the state level and regulates a wide range of economic relations (sales, rent, working capital, bank deposits and collection operations, electronic funds transfers, letters of credit, comprehensive sales, warehouse certificates, investment securities, security contracts, etc.).

The Uniform Commercial Act is used not only by the state legislators to unify the United States of America's trade law. The achievements of the Uniform Commercial Code were taken into account by the European legislators when elaborating the European Union "model" documents in years 1997 and 2003. Currently, there is a reverse trend, when the Principles of the European Contract Law, which have absorbed the experiences of trade law of the European Union as well as the international conventions, are among the most important sources for modifying the Uniform Commercial Code.

So, the above-mentioned comparisons prove that the existence of the Commercial Code is typical for the developed and developing states.

\section{Conception of commercial law reform in Ukraine}

In opposite of the above-mentioned facts, the Concept of Civil Legislation Reform in Ukraine ${ }^{17}$ states that the systematic renewal of the Civil Code of Ukraine as a whole is possible only if the Commercial Code of Ukraine is repealed. The latter does not meet the parameters of the acts governing business relations which, by their nature, are primarily private. Thus, the reform of civil legislation is seen only if the Commercial Code of Ukraine is repealed, as it is outdated, contains many "archaic" legal institutions and does not meet the market conditions of legal regulation of business relations. At the same time, no vision is proposed for a future act (number of acts) that should regulate the relevant legal relationships.

vate Law]. 1966, Jg. 30, Nr. 3, pp. 403-413. ISSN 0033-7250; and MILLER, F. H., P. B. FRY and J. P. BURTON. Introduction to Uniform Commercial Code Annual Survey: The Centennial of the National Conference of Commissioners on Uniform State Laws. The Business Lawyer. 1991, vol. 46, no. 4, pp. 1449-1454. ISSN 0007-6899.

${ }^{17}$ See KOVALSKYI, V. S. Concept of Updating the Civil Code of Ukraine. In: Yurinkom Inter [online]. 2021-01-21 [cit. 2021-03-31]. Available at: https://yurincom.com/legal_news/ new_legislation/kontseptsiia-onovlennia-tsyvilnoho-kodeksu-ukrainy/ [in the Ukrainian original КОВАЛЬСКИЙ, В. С. Концепція оновлення Цивільного кодексу України. В: Юрінком Інтер [онлайн]. 2021-01-21 [цит. 2021-03-31]. Доступно на: https://yurincom.com/legal_news/new_legislation/kontseptsiia-onovlennia-tsyvilnoho-kodeksuukrainy/]. 
Unfortunately, there is an opinion among the Ukrainian representatives of civil law that the economic code is a relic of the past and the very idea of a single codified act in the field of economics does not correspond to modern trends in legal regulation of business relations.

The Concept of Civil Legislation Reform in Ukraine proposes to enshrine in the Civil Code of Ukraine an exhaustive list of organizational and legal forms of legal entities. The Civil Code of Ukraine as a fundamental act of private law, which including general provisions regulates legal entities, should define an exhaustive list of their organizational and legal forms while abandoning the archaic structures of legal entities (especially enterprises). For legal entities that are registered in other organizational and legal forms, it is proposed to provide time to bring their organizational and legal form in line with the provisions of the Civil Code of Ukraine within the period to be established by the law.

On the one hand, implementation of the proposed Concept of Civil Legislation Reform in Ukraine, which is based on the idea of a "soft recodification", should preserve all the achievements of the current Civil Code of Ukraine and, on the other hand, should adapt it to modern realities, including modern civil and business turnover, which is characterized by digitalization of all processes in society, deep penetration of new technologies into business, priority application of the European Court of $\mathrm{Hu}-$ man Rights judgments and other international human rights instruments, support of international initiatives for the information society development, conscious use of automated robots and artificial intelligence, reproductive technologies and genetic engineering, increasing the role of dispositiveness in contractual regulation, and so on.

\section{Conclusions}

Based on the facts presented and analyses carried out in our paper, we can finally summarize the following conclusions:

1. With regard to the proposals expressed in the Concept of Civil Legislation Reform in Ukraine, we would like to note that undoubtedly the Commercial Code of Ukraine as well as the Civil Code of Ukraine need some updating. There is an urgent need to systematize the existing organizational and legal forms of legal entities and to renew the basics of civil law regulation in Ukraine. 
2. However, there are no grounds for repealing the Commercial Code of Ukraine. Commercial (trade) codes continue to be the legislative basis on which the whole array of the centuries-old law institutions functions.

3. While in most neighbouring jurisdictions steps are being taken to systematic update of the commercial codes (including expanding the scope of their legal regulations), in Ukraine steps are being taken to eliminate the commercial code. This seems completely unacceptable; it harms significantly the legal regulation of business relations in Ukraine and slows down the progressive development of the Ukraine's economy.

4. The analysis of the commercial codes abroad shows that there is no single approach to the list of legal constructions that should form the basis of the relevant code. All, without exception, codified acts of this type are characterized by the presence of special institutions that, from the point of foreign lawyer's view or current trends in private law, may seem do not meet certain standards. But such a situation does not give grounds for the elimination of the relevant commercial code. Therefore, the Ukrainian legislator should take the way of modernizing and not of repealing the Commercial Code of Ukraine.

Acknowledgements

This paper was written in the framework of the Jean Monnet Module "Commercial Law of the European Union" and was financed with the support of the Erasmus+ Programme of the European Union.

\section{References}

Civil Code of Ukraine [online]. 2021 [cit. 2021-03-31]. Available at: https://zakon.rada.gov.ua/laws/show/435-15.

Code de commerce. 54e éd. Paris: Jurisprudence générale Dalloz, 1958. $963 \mathrm{p}$.

Commercial Code of Ukraine [online]. 2021 [cit. 2021-03-31]. Available at: https://zakon.rada.gov.ua/laws/show/436-15.

Constitution of Ukraine of 28 June 1996, No. 254k/96-BP, as amended.

Handelsgesetzbuch [online]. 2021 [cit. 2021-03-31]. Available at: https:// www.gesetze-im-internet.de/hgb/.

Kodeks spółek handlowych [online]. 2021 [cit. 2021-03-31]. Available at: http://isap.sejm.gov.pl/isap.nsf/download.xsp/WDU20000941037/ U/D20001037Lj.pdf. 
KOŁACZ, J. Polish Company Law: A Few Remarks on Legal History and Foreign Inspirations. Social Science Research Network Electronic Paper Collection [online]. 2009, no. 3, pp. 1-36 [cit. 2021-03-31]. Available at: https://doi.org/10.2139/ssrn.2020231.

KOVALSKYI, V. S. Concept of Updating the Civil Code of Ukraine. In: Yurinkom Inter [online]. 2021-01-21 [cit. 2021-03-31]. Available at: https://yurincom.com/legal_news/new_legislation/kontseptsiiaonovlennia-tsyvilnoho-kodeksu-ukrainy/ [in the Ukrainian original КОВАЛЬСКИЙ, В. С. Концепція оновлення Цивільного кодексу України. В: Юрінком Інтер [онлайн]. 2021-01-21 [цит. 2021-0331]. Доступно на: https://yurincom.com/legal_news/new_legislation/kontseptsiia-onovlennia-tsyvilnoho-kodeksu-ukrainy/].

MARTIN, J. S., C. P. MARKS and W. BARNES. The Uniform Commercial Code Survey: Introduction. The Business Lawyer. 2015, vol. 70, no. 4, pp. 1161-1164. ISSN 0007-6899.

MAYDANYK, R. Contract and Corporate Law of Ukraine: Evolution and Trends. In: P. PINIOR, W. WYRZYKOWSKI and M. ŻABA, eds. Evolution of Private Law: New Perspectives. 1. wyd. Katowice: Oficyna Wydawnicza Wacław Walasek, 2018, pp. 54-65. ISBN 978-83-65694-577.

MENTSCHIKOFF, S. The Uniform Commercial Code. Rabels Zeitschrift für ausländisches und internationales Privatrecht [The Rabel Journal of Comparative and International Private Law]. 1966, Jg. 30, Nr. 3, pp. 403-413. ISSN 0033-7250.

MILLER, F. H., P. B. FRY and J. P. BURTON. Introduction to Uniform Commercial Code Annual Survey: The Centennial of the National Conference of Commissioners on Uniform State Laws. The Business Lawyer. 1991, vol. 46, no. 4, pp. 1449-1454. ISSN 0007-6899.

Resolution of the Cabinet of Ministers of Ukraine on the Establishment of a Working Group on Recodification (Updating) of Civil Legislation of Ukraine No. 650 [2019-07-17] [online]. 2019 [cit.2021-03-31]. Available at: https://www.kmu.gov.ua/npas/pro-utvorennya-robochoyi-grupi-shchodo-rekodifikaciyi-onovlennya-civilnogo-zakonodavstva-ukrayini-s-650-170719.

SOŁTYSIŃSKI, S. and A. SZUMAŃSKI. Shareholder and Creditor Protection in Company Groups under Polish Law. In: K. J. HOPT, Ch. JESSELHOLST and K. PISTOR, Hrsg. Unternehmensgruppen in mittel- und 
osteuropäischen Ländern: Entstehung, Verhalten und Steuerung aus rechtlicher und ökonomischer Sicht. 1. Aufl. Tübingen: Mohr Siebeck, 2003, pp. 89-104. Beiträge zum ausländischen und internationalen Privatrecht, Nr. 76. ISBN 3-16-148089-9.

SOŁTYSIŃSKI, S. Reform of Polish Company Law. In: B. GROSSFELD, R. SACK, Th. M. J. MÖLLERS, J. DREXL and A. HEINEMANN, Hrsg. Festschrift für Wolfgang Fikentscher zum 70. Geburtstag. 1. Aufl. Tübingen: Mohr Siebeck, 1998, pp. 419-433. ISBN 3-16-146704-3.

Tax Code of Ukraine of 2 December 2010, No. 2755-VI, as amended.

Unternehmensgesetzbuch [online]. 2021 [cit. 2021-03-31]. Available at: https://www.ris.bka.gv.at/GeltendeFassung.wxe?Abfrage=Bundesno rmen\&Gesetzesnummer $=10001702$.

VASYLIEVA, V. A. ed. Company Law of Austria and Ukraine: Monograph. Ivano-Frankivsk: Vasyl Stefanyk Precarpathian National University, 2015. 250 p. ISBN 978-966-640-411-7 [in the Ukrainian original BAСИЛЬЄВА, В. А. ред. Корпоративне право Австрії та України: Монографія. Івано-Франківськ: Прикарпатський національний університет імені Василя Стефаника, 2015. 250 с. ISBN 978-966-640411-7].

Zákon č.90/2012 Sb. o obchodních společnostech a družstvech (zákon o obchodních korporacích) [online]. 2021 [cit. 2021-03-31]. Available at: https://www.zakonyprolidi.cz/cs/2012-90.

Assoc. prof. Oleksandr Romanovich Kovalyshyn, Ph.D.

Educational-scientific Institute of Law Vasyl Stefanyk Precarpathian National University Shevchenko St. 44 A 76018 Ivano-Frankivsk Ukraine oleksandr.kovalyshyn@pnu.edu.ua https://orcid.org/0000-0003-2019-4474 